\title{
水害被災地の復興とコミュニティ意識 (2)
}

\author{
○今井芳昭 - 大島 尚 - 田中 淳 - 加藤 司 - 片山美由紀 - 安藤清志 \\ (東洋大学社会学部) \\ key words : コミュニティ、ソーシャル・キャピタル、水害
}

\section{目 的}

自然災害を被った場合、回復度や災害に対する住民意識に 差はあるのであろうか。あるとすれば、それにはどのような 要因が関わっているのであろうか。その要因の1つとして、 Putnam (2000)の提唱したソーシャル・キャピタルという概念 を挙げることができよう。彼によればソーシャル・キャピタ ルとは「信頼や互酬性の規範が成り立っている網の目上の社 会ネットワークとそこに埋め込まれた社会的資源」である。

自然災害のうち、日本において比較的発生しやすいものと して水害がある。2004年には新潟県 A市、同県 B 町、兵庫県 C市、京都府 D町の 4 地域において多大な被害を受けた。本 研究においては、これら 4 地域における水害からの回復とソ ーシャル・キャピタルとの関連性を明らかにしようとするも のである。

一般的には、ソーシャル・キャピタルの程度が高い地域ほ ど、水害からの回復度が大きく、水害後であっても積極的に ポジティブに近隣を認知すると予測できるであろう。

\section{方 法}

＜回答者＞上記 4 地域のうち床上浸水のあったエリアを サンプリングし、20歳以上の個人を対象に調查員による訪問 留置法でデータを収集した。520人を抽出して質問紙を配布し、 362 人から回収した（有効回収率 $=69.6 \%$ ）。調查時期は2006 年2月 25 日〜3月7日であった。なお、 $\mathrm{A}$ 市とC市の回答者数は、 それぞれ 112 人と 117 人、20～30歳代、40～50歳代、60歳以上 がそれぞれ 3 割、 4 割、3 割という年代構成であった。B 町 69人、D町64人であり、後者の年代構成は、 2 割、3 割、5 割であり、他地域より高齢者の比率が多かった（詳細につい ては、大島ら (2006、前頁)、田中・大島 (2006) を参照)。 ＜質問紙＞質問紙は、被害状況 7 項目、回復状況 5 項目、 水害後の生活状況10項目、ソーシャル・キャピタル 9 項目、 行政への希望事項 9 項目から構成されていた。

\section{結 果}

<ソーシャル・キャピタル尺度＞大島・片山・安藤 (2005) は、Putnam (2000)を基にしてソーシャル・キャピタルを測定 する質問項目を 8 項目作成した。今回は、それに 1 項目を追 加したものを使用した。

全回答者のデータを用いて因子分析を行い、2 因子解（主 因子法、プロマックス法）を採用することにした。それぞれ 「地域・住民認知」因子 $(7$ 項目、 $\alpha=.74$ 、「近所の人とは誰 であれ親しくおつきあいしたい。次世代のためにこの地域を よくしたい。困っているときに近所の人は助けてくれる。地

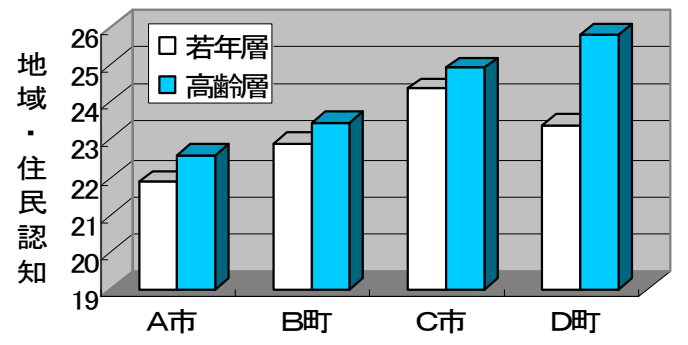

図1 各地域の「地域·住民認知」得点
域を暮らしよくするためには住民の努力が必要だと思う。こ れからもこの地域に住み続けたい」など)、「圧迫感」因子( 2 項目、 $\alpha=.52$ 、「知らない人たちの中に加わるとき気詰まり に感じる。毎日の生活や仕事で押しつぶされそうになる」) と命名した（累積説明率 $=48.21 \%$ 、因子間相関 $=.47$ ）

<ソーシャル・キャピタルに関する 4 地域の比較 $>$ 各項目 の得点を加算し、4 地域を比較した。その際、年齢について 中央值分割して高群 (52歳以上) と低群を設定し、2 要因の分 散分析を行った。「地域・住民認知」（範囲 $=7 \sim 49 ）$ に関し て地域要因 $(F(3,252)=14.61, p<.001)$ と年齢要因 $(F(1$, $252)=7.21, p<.001$ )の主効果が認められた（図 1)。多重比 較 (Tukey HSD, $p<.05)$ の結果、C市 $=\mathrm{D}$ 町 $>\mathrm{B}$ 町 $>\mathrm{A}$ 市とい う順に「地域住民認知」得点が高いこと、また、高齢層の方 が若年層よりも高いことが見出された。

「圧迫感」についても地域要因と年齢要因の主効果のみが 認められ、A市、B町の值の大きいことが認められた。

くソーシャル・キャピタルと回復状況との相関＞地域ごと に「地域・住民認知」と回復状況 ( 5 項目の総和、 $\alpha=.71$ ) と の相関係数を算出したが、いずれの地域においても有意な值 は認められなかった。

<水害後の近隣に対する認知 $>$ 水害後の近隣の人々に対 する積極的な関わりを測定した10項目の内、8 項目の一次元 性が確認された $(\alpha=.94$ 、「近所の人たちと互いに気遣うよう になった。地域の人々と一体感を感じるようになった。顔を 合わせると挨拶をする人が増えた」など）。

その総和について分散分析を行ったところ、地域要因 $(F(3$, $354)=54.89, p<.001)$ と年齢要因 $(F(1,354)=26.23, p<.001)$ の主効果が認められた。多重比較を行ったところ、 D町 $>C$ 市> B 町>A市の順で近隣に対する認知がポジティブであり、 また、高齢層の方がポジティブであることが認められた。 くソーシャル・キャピタルと水害後の近隣認知との相関 $>$ 地域ごとに「地域・住民認知」と「水害後の近隣認知」との 相関係数を算出したところ、A市 (. 48)、C市 (. 53)、D町 (. 42、 いずれも $p<.01)$ において有意な值が認められた。

\section{考 察}

ソーシャル・キャピタルに関する 2 因子について地域間に 差が認められた。今後、C市やD町のソーシャル・キャピタ ルを大きくしている要因を特定していくことが必要である。

また、「地域住民認知」と回復状況との相関は特に認められ ず、水害後の近隣に対する認知との相関において、B町を除 く3 地域で有意な值が認められた。元々、近隣に対してポジ ティブな認知をもっているほど、水害という被害を受けた後 も近隣に積極的な関わりをもっていることが伺える。

\section{引用文献}

田中 淳・大島 尚 (2006) 「2004 年水害被災地における 復興の現状と意識」調査報告 東洋大学 21 世紀 HIRC 研究 年報, 3, 81-88.

(IMAI Yoshiaki, OHSHIMA Takashi, TANAKA Atsushi, KATO Tsukasa, KATAYAMA Miyuki, ANDO Kiyoshi)

本研究は文部科学省オープンリサーチセンター整備事業の一部と して行われたものである。 